\title{
A BREAK-EVEN ANALYSIS AND IMPACT ANALYSIS OF RESIDENTIAL SOLAR PHOTOVOLTAIC SYSTEMS CONSIDERING STATE SOLAR INCENTIVES
}

\author{
Minhyun LEE ${ }^{\mathrm{a}}$, Taehoon $\mathrm{HONG}^{\mathrm{b}}$, Choongwan $\mathrm{KOO}^{\mathrm{c}}$, Chan-Joong $\mathrm{KIM}^{\mathrm{d}}$ \\ ${ }^{a, b}$ Department of Architectural Engineering, Yonsei University, Seoul, 03722, Republic of Korea \\ ${ }^{c}$ Department of Building Services Engineering, Faculty of Construction and Environment, \\ The Hong Kong Polytechnic University, Hong Kong \\ ${ }^{d}$ NOWArchitects Co, Ltd, Seoul, 06770, Republic of Korea
}

Received 21 April 2015; accepted 25 November 2015

\begin{abstract}
Despite the steady growth and price reductions of solar photovoltaic (PV) market in the United States (U.S.), the solar PV market still depends on financial support and incentives due to its high initial investment cost. Therefore, this study aimed to conduct a break-even analysis and impact analysis of residential solar PV systems by state in the U.S., focused on state solar incentives. Three indexes (i.e., net present value, profitability index (PI) and payback period) were used to evaluate the investment value of the residential solar PV systems considering state solar incentives. Furthermore, PI increase ratio was used to analyze the impact of state solar incentives on the economic feasibility of the residential solar PV systems in each state. As a result, it was found that 18 of the 51 target cities have reached the break-even point and seven of the 51 target cities showed great improvement of the economic feasibility of solar PV systems in the U.S. due to excellent state solar incentives. The results of this study can help policy makers to evaluate and compare the economic impacts of the residential solar PV systems by state in the U.S.
\end{abstract}

Keywords: solar photovoltaic systems, solar policy, state solar incentives, break-even analysis, life cycle cost, United States.

JEL classification: Q48, L78, D78, Q01, Q21, D81, E27, Q47, L74.

\section{Introduction}

The worldwide interest in New Renewable Energies (NRE) has increased to cope with global crises such as climate change and environmental pollution. Among the various types of NRE, solar photovoltaic (PV) energy is the fastest growing sustainable energy source (Koo et al. 2013, 2014a; Lee et al. 2014). The European Union (EU) and the United States (U.S.) are leading the growth of the global solar PV market (IREC 2013).

Corresponding author Taehoon Hong

E-mail: hong7@yonsei.ac.kr 
The solar PV market in the U.S., however, still depends on solar policies and incentives due to its high initial investment cost (IEA 2011). Unlike most other countries, where such policies and incentives are established at the national level, policies and incentives differ at the state level in the U.S. (Burns, Kang 2012). Renewable portfolio standard (RPS), one of the representative NRE policies in the U.S., is a regulation that mandates electric utilities (i.e., electricity supply companies, which provide energy services to the customers in their respective regions) to produce a certain percentage of their electricity from NRE (Hong, Jung 2012). Solar carve-outs, which have been implemented as part of RPS, is a regulation that mandates electric utilities to meet a certain percentage of the RPS in terms of solar energy due to its high initial investment cost (DSIRE 2015). The electric utilities that are required to comply with such RPS and the solar carve-outs are operated not at the national level but at the state or local level. Thus, the solar incentives provided by the state government and electric utilities differ at the state level (SolarPowerRocks 2015).

Meanwhile, in the U.S., solar radiation and electricity prices, the key factors for determining the economic performance of the solar PV system, differ significantly by state, causing a difference in the return on investment and break-even point (Swift 2013). Therefore, it is necessary to consider the key factors, which differ by state, to analyze the economic feasibility of the solar PV system in the U.S.

However, previous studies, which attempted to conduct the economic analysis of the solar PV system, had the following limitations: (i) Lack of comprehensive analysis of the regional factors in all the states in conducting the economic analysis of the solar PV system; and (ii) Lack of comprehensive analysis of all types of solar incentives in the states in conducting the economic analysis of the solar PV system.

To overcome these limitations, this study conducted multilateral analysis of state solar incentives in all 50 states and the District of Columbia in the U.S. To consider the various state solar incentives and analyze the impact of these incentives, this study conducted a break-even analysis and impact analysis of residential solar PV systems using life cycle cost (LCC) and life cycle $\mathrm{CO}_{2}\left(\mathrm{LCCO}_{2}\right)$ analyses. This study was conducted in four steps: (i) data collection of solar radiation, electricity prices, and solar incentives by state; (ii) electricity generation calculation using RETScreen; (iii) defining assumptions for LCC and $\mathrm{LCCO}_{2}$ analyses; and (iv) economic assessment of the residential solar PV systems by target city in each state (refer to Supplementary Information (SI), SI Figure S1).

\section{Literature review}

There have been previous studies that conducted the economic analysis of the solar PV system. First, several studies conducted the economic analysis of the solar PV system by considering regional factors, including solar incentives (Burns, Kang 2012; Swift 2013). Burns and Kang (2012) conducted an economic analysis of solar policies in states with solar renewable energy certificates (SREC), which showed that New Jersey, Delaware, and Massachusetts had the strongest SREC market. Jiang and Zhu (2012) analyzed the impact of solar incentives and system efficiency on the economic performance of the residential solar 
PV systems installed in Florida. The results showed that PV systems with larger capacity benefit from higher rebate cap while PV systems with smaller capacity benefit from higher rebate rates. Swift (2013) compared and analyzed the cost and financial returns of commercial solar PV systems in four regions in the U.S. using the levelized cost of electricity (LCOE). The results showed that as solar radiation, electricity prices, and solar incentives differed by region, the cost and financial returns of the solar PV system also showed a drastic difference by region. These previous studies partially considered regional factors, but failed to consider the overall solar incentives and regional factors.

Second, other studies conducted the economic analysis of the solar PV system by considering the uncertainties of various assumptions (Branker et al. 2011; Darling et al. 2011). Branker et al. (2011) conducted a sensitivity analysis of various assumptions and derived important variables that would affect the LCOE of the solar PV system. An example of Ontario in Canada showed that system costs, financing, useful life, and loan term were the important variables of LCOE. Darling et al. (2011) used a stochastic approach in considering the uncertainties of the assumptions in calculating the LCOE of the solar PV system. They used Monte-Carlo simulation to establish the assumptions on solar radiation, solar PV panel performance, operation and maintenance costs, and the inflation rate. These previous studies considered the uncertainties related to various assumptions for the economic analysis, but failed to consider key regional factors, such as solar incentives.

Third, other studies conducted the economic analysis of the solar PV system outside of the U.S., especially in EU, by considering solar incentives (Ameli, Kammen 2014; Antonelli, Desideri 2014; Frondel et al. 2010; Hass et al. 2011; Laleman, Albrecht 2014). Ameli and Kammen (2014) developed a financing tool based on a pollution abatement methodology in order to examine options to bridge the cost gap between solar PV and other energy generation technologies in Italy. The results showed that well-designed Property Assessed Clean Energy (PACE) loan program, as an alternative to subsidy programs (i.e. feed-in tariff), would be an effective tool to achieve solar grid parity without burdening public budgets. Hass et al. (2011) evaluated the performance of various promotion strategies electricity from renewable energy sources within the EU Member States. The study concluded that technology-specific financial support measures were more effective than other strategies, implying that how promotion strategies are designed and implemented for each technology is the key solution, not what kind of support instrument is selected and implemented. These previous studies evaluated the economic aspects of various solar incentives and proposed effective solutions, but failed to apply these lessons to other regional sectors (i.e. the U.S. etc.).

\section{Current status of solar incentives in the United States}

Solar incentives in the U.S. differ by state or region as RPS and solar carve-outs do. Solar incentives can generally be categorized into tax incentives and cash incentives. Tax incentives include income tax credit and tax exemption whereas cash incentives include capacitybased incentives and performance-based incentives (refer to Table 1). 
Table 1. Solar incentives in the U.S.

\begin{tabular}{lll}
\hline \multicolumn{1}{c}{ Class 1 } & \multicolumn{1}{c}{ Class 2 } & \multicolumn{1}{c}{ Class 3 } \\
\hline Tax incentives & Income tax credit & Federal income tax credit \\
\cline { 2 - 3 } & Tax exemption & State income tax credit \\
\cline { 2 - 3 } & Capacity-based incentives & Sales tax exemption \\
\cline { 2 - 3 } & Performance-based incentives & Stility rebate program \\
\cline { 2 - 3 } & State program \\
\cline { 2 - 2 } & & Utility program \\
\cline { 2 - 2 } & & Solar renewable energy certificates (SREC) \\
\hline
\end{tabular}

\subsection{Tax incentives}

\subsubsection{Income tax credit}

Income tax credit, which offers tax credit for the installation cost of the solar PV system, can be categorized into federal and state income tax credit. Federal income tax credit is a solar incentive granted to all states in the U.S., and the taxpayer gets credit which accounts for $30 \%$ of the installation cost of the solar PV system. State income tax credit is a statebased solar incentive, and its implementation and the amount of credit differ by state. If a state government offers state income tax credit, both federal and state income tax credits can be granted to the taxpayer (Burns, Kang 2012; Jiang, Zhu 2012; Swift 2013).

\subsubsection{Tax exemption}

Tax exemption can generally be categorized into property and sales tax exemption. Property tax exemption is a solar incentive that exempts the property tax charged for the increased home value due to the installation of the solar PV system. Sales tax exemption is a solar incentive that exempts the sales tax from the installation cost of the solar PV system. Tax exemption is a state-based solar incentive, and thus, it differs by state (DSIRE 2015).

\subsection{Cash incentives}

\subsubsection{Capacity-based incentives}

Capacity-based incentives are solar incentives where the incentive rate is offered based on the installed capacity of the solar PV system (dollar per Watt), and are generally paid as up-front incentives. Capacity-based incentives can be generally categorized into state rebate programs (in which the state government offers solar incentives) and utility rebate programs (in which electric utilities offer solar incentives). As the state rebate program offers solar incentives throughout the state, all the regions in the state can receive the incentives in installing the solar PV system. The utility rebate program, however, can be applied only to the service region of the corresponding electric utilities in which grid-connected power plants or residential solar PV systems are installed, and thus, its implementation and the amount of incentives may even differ within the state. With the capacity-based incentives, 
the budget is generally limited, and the incentives are offered on a first-come, first-served basis; thus, even in a region covered by the program, it is not guaranteed for all customers to receive the solar incentives (Burns, Kang 2012). Additionally, the capacity-based incentives decline over time as the statewide installed capacity of the solar PV system increases. Therefore, the more delayed the installation of the solar PV system, the more difficult it comes to receive a higher amount of incentives.

\subsubsection{Performance-based incentives}

Performance-based incentives are solar incentives where incentive rate is offered based on the electricity generated by the solar PV system (dollar per kilowatt-hours), and are generally paid annually. Performance-based incentives are categorized into state programs (where solar incentives are offered by state), utility programs (where solar incentives are offered by electric utilities), and SREC (a certificate issued for generating electricity by the solar PV system). Generally, performance-based incentives are offered as a form of the utility program and SREC. The ownership of SREC is usually transferred to electric utilities for utility programs. As the state program and SREC are operated by the state government, incentives are offered in all the regions in the state for installing the solar PV system. On the other hand, similar to the utility rebate program under capacity-based incentives, the utility program offers incentives only to the electric utility territory, and thus, its implementation and the amount of incentives may even differ within the state. As a type of REC, an SREC is issued for every $1 \mathrm{MWh}$ of electricity generated by the installed solar PV system. Besides the profits from the sales of the generated electricity, SREC offers additional economic value and symbolizes "green value". In the SREC market, SREC prices differ based on the supply and demand of SREC and SREC can be sold to electric utilities, which are mandated to supply NRE. The highest price of SREC can be determined by the solar alternative compliance payment (SACP), which must be paid when the solar energy supply compliance could not be met (SRECTrade 2015).

\section{Materials and methods}

The U.S. provides various solar incentives, and the type and the amount of incentives differ by state. The previous studies on the economic analysis of the solar PV system failed to consider the regional diversity of solar incentives. To address this challenge, this study aimed to conduct a break-even analysis and impact analysis of residential solar PV systems considering the state solar incentives in the U.S.

\subsection{Step 1: Data collection}

As the solar radiation, electricity prices, and solar incentives in the U.S. differ by state, the economic performance of the solar PV system shows a considerable difference. Therefore, it is required to determine the key factors affecting such systems, such as solar radiation, electricity prices, and solar incentives for an economic assessment of the solar PV systems. This study established the database on solar radiation, electricity prices, and solar incentives in the 50 states and the District of Columbia in the U.S. 


\subsubsection{Step 1.1: Solar radiation}

The solar radiation data for each state is a key factor affecting solar PV system performances in various states. This study collected solar radiation data from the weather data provided by RETScreen, an NRE simulation program.

\subsubsection{Step 1.2: Electricity price}

The electricity price data for each state is provided by U.S. Energy Information Administration (EIA 2015). As there are various electric utilities in a state, EIA provides data on the average retail price of electricity. The data consists of four sectors (i.e., residential, commercial, industrial, and transportation sectors), and the weekly and monthly electricity data in each of the sectors are provided. Therefore, this study collected the data on the residential average retail price of electricity in 2012 by state, which is provided by EIA. SI Figure S2 shows the residential average retail price of electricity by state.

In SI Figure S2, the greener the color of the state is, the higher the residential average retail price of electricity is compared to the other states. The higher the residential average retail price of electricity is, the more remarkable is the economic value from the electricity generated by the solar PV system. In Hawaii, for example, the residential average retail price of electricity was US $\$ 0.37 / \mathrm{kWh}$, which was considerably higher than the average price in the U.S. (US\$0.12/kWh), signifying that the expected profit from the installation of the solar PV system in Hawaii would be very high. Besides Hawaii, in most of the states located in the northeastern part of the U.S., such as Alaska, New York, Connecticut, Vermont, New Hampshire, and New Jersey, the residential average retail price of electricity was over US $\$ 0.15 / \mathrm{kWh}$. California in the southwestern part of the U.S. also showed a high residential average retail price of electricity, which was over US $\$ 0.15 / \mathrm{kWh}$.

\subsubsection{Step 1.3: State solar incentives}

The NRE policy and incentive data by U.S. state is provided by the Database of State Incentives for Renewables and Efficiency (DSIRE), which is developed by North Carolina Solar Center at North Carolina State University (DSIRE 2015). As shown in Table 1, the solar incentives in the U.S. are generally categorized into tax incentives (i.e., income tax credit and tax exemption) and cash incentives (i.e., capacity-based incentives and performancebased incentives), which are offered in various forms by state.

SI Figures S3 and S4 show the residential solar incentives by state. SI Figure S3 show the current status of all the solar incentives (i.e., tax incentive credit and tax exemption) offered by the U.S. There are 22 states that are offering only cash incentives (illustrated in light green color on the map), more than twice the number of states that are offering both state income tax credit and cash incentives (10 states, illustrated in dark green color on the map), and more than four times the number of states that are offering only state income tax credit (five states, illustrated in orange color). In the case of tax exemption, 33 states are offering either property tax exemption or sales tax exemption, and more than half of the states are offering tax exemption. On the other hand, seven states are offering the state income tax credit, tax exemption, and cash incentives, and nine states do not offer any of 
the solar incentives. SI Figure S4 shows the current status of only cash incentives offered by the U.S. 15 states are offering only capacity-based incentives (illustrated in orange color on the map), seven states are offering only performance-based incentives (illustrated in light green color on the map), and ten states are offering both capacity-based incentives and performance-based incentives (illustrated in dark green color on the map), which show that most of the states are offering capacity-based incentives. Only nine states have the SREC market, and many of the other states do not have one.

\subsubsection{Step 1.4: Selection of the target cities in each state}

Although the solar incentives in the U.S. are being offered at the state level, different incentives may be available even within the same state according to the region and city, due to incentives like the utility rebate program. Therefore, 51 target cities were selected from the 50 states of the U.S. and the District of Columbia based on the following criteria:

- The metropolitan city that has the largest population in each state (its solar incentives were used for the analysis); and

- In Florida and Texas, the city with the second largest population (the city with the largest population in these states, respectively, was Jacksonville and Huston, but the solar radiation of such cities was shown to be considerably low).

SI Table S1 (i.e., SI Tables S1A and S1B) shows the analysis results of the solar incentives in the 51 target cities. Even if the cities have the same types of solar incentives, each state offers solar incentives in different rates and forms. First, state income tax credit and tax exemption, which are tax incentives, can be offered to all regions within the state. As of 2013, 33 states are providing state income tax credit, offering 10\% 50\% of the tax credit with caps ranging US\$1,000 US\$12,500. As of 2013, tax exemption is available in 33 states, 17 of which offer a $100 \%$ property and sales tax exemption. Second, capacity-based incentives are categorized into solar rebate programs offered by the state government (which can be applied to all regions within the state) and utility rebate programs (which can be applied only to the regions that are covered by the service area of electric utilities). As of 2013 , the states pay US $\$ 200 / \mathrm{kW} \sim \mathrm{US} \$ 3,000 / \mathrm{kW}$ for the capacity-based incentives. Third, performance-based incentives are categorized into state programs and SREC (which can be applied to all regions within the state) and utility programs (which can be applied only to the region covered by the service area of electric utilities). Only two states, South Carolina and Washington, have state programs, which offer US $\$ 0.1 / \mathrm{kWh}$ and US $\$ 0.15 / \mathrm{kWh}$, respectively. Unlike the other incentives, SREC prices fluctuate based on the market supply and demand, and are not fixed. PJM Interconnection (Pennsylvania-New Jersey-Maryland Interconnection), a regional transmission organization that coordinates the movement of wholesale electricity in 13 U.S. states and the District of Columbia, operates Generation Attribute Tracking System (GATS), the REC tracking system, to manage the information on the issuance, registration, transaction, and expiration of REC (KPX 2009; PJM 2015). Thus, this study used the solar weighted average price provided by GATS (GATS 2015). As of 2013, the solar weighted average price per SREC is US\$97 US\$397 by state, and the average trading price is US\$190. As of 2013, the utility program in each state offers incentives ranging US\$0.03/kWh US\$0.19/kWh. 
Meanwhile, Boston in Massachusetts is offering all types of solar incentives, a total of five incentives. There are eight cities that are offering four solar incentives, 14 cities offering three incentives, 12 cities offering two incentives, and eight cities offering only one incentive. On the other hand, nine cities do not offer any solar incentive.

\subsection{Step 2: Electricity generation calculation}

To calculate the electricity generation of the solar PV system in the target cities in each state, this study used RETScreen, an NRE simulation program, which was co-developed by the Department of Natural Resources in Canada and the United Nations Environment Programme and is believed to have public confidence (Koo et al. 2014b, 2014c; Minister of Natural Resources 2004, 2010). To calculate the simulation-based electricity generation using RETScreen, this study first defined assumptions for solar PV system installation and operation. Based on these assumptions, this study calculated the simulation-based electricity generation using RETScreen.

\subsubsection{Step 2.1: Assumptions for solar PV system installation and operation}

Assumptions for solar PV system installation should first be defined to calculate the simulation-based electricity generation. Furthermore, assumptions for solar PV system operation should be defined to conduct LCC analysis of solar PV systems. Thus, assumptions for solar PV system installation and operation were set as below:

- Capacity of the solar PV system: on average, the capacity of the residential solar PV system in the U.S. is between $2 \mathrm{~kW}$ and $10 \mathrm{~kW}$ (Burns, Kang 2012). Particularly, key reports on the economic analysis of residential solar PV systems in the U.S. usually assumed that the capacity of the residential solar PV system is about $5 \mathrm{~kW}$ (Open PV Project Break-even Analysis 2015; SolarPowerRocks 2015). Accordingly, this study assumed that the capacity of the residential solar PV system is $5 \mathrm{~kW}$;

- Weather data of the target cities: solar radiation, among the weather data, differs significantly by state, and thus considerably affects the electricity generation of the solar PV system. This study used the weather data from RETScreen by city;

- Azimuth and slope of the solar PV system: the solar PV system offers the highest electricity generation when it faces south, and its optimal slope differs by region (Hong et al. 2014a). Therefore, this study set $0^{\circ}$ as the azimuth of the solar PV system, which has a southern orientation. This study set the optimal slope of the PV system in each target city, at which the electricity generation of the solar PV system calculated by RETScreen is at its maximum;

- PV panel and inverter type: the solar cell, a component of the PV panel, is categorized into crystalline silicon cell and amorphous silicon cell based on the material. In the solar PV market, the monocrystalline and multi-crystalline modules are the most widely used among the crystalline silicon cells (CEC 2001). Based on Global Status 
Report 2013 and PV Inverter World Market Report 2014, this study selected and used YingliSolar's PV panel in the simulation (which has the highest solar PV market share) and SMA's inverter (which has the highest solar PV inverter market share) (HIS Technology 2014; REN21 2013) (refer to SI Table S2); and,

- Degradation rate of the solar PV system: based on previous studies and the actual PV panel data, the solar PV panel performance is degraded by $20 \%$ during its 25 -year service life (Burns, Kang 2012; Swift 2013; Yingli Solar 2015). This study set $0.8 \%$ as the annual degradation rate of the solar PV system.

\subsubsection{Step 2.2: Electricity generation calculation of the solar PV system by state}

Based on the assumptions for solar PV system installation and operation, this study calculated the electricity generation of the solar PV system by target city in each state. In SI Figure S5, the greener the color of the state is, the greater the electricity generation of the solar PV system in the target cities in that state. The electricity generation of the solar PV system increases towards the southwest. Particularly, Las Vegas in Nevada and Albuquerque in New Mexico were shown to generate the highest electricity from the solar PV system. Namely, the expected profits in installing the solar PV system were highest in these two cities. The lowest electricity generation of the solar PV system was shown in Anchorage in Alaska, Seattle in Washington, D.C., and Portland in Oregon (illustrated in orange color on the map). Namely, these cities were shown to produce the lowest expected profits in installing the solar PV system.

\subsection{Step 3: Defining assumptions for $\mathrm{LCC}$ and $\mathrm{LCCO}_{2}$ analyses}

Assumptions on various factors should be defined to conduct an economic assessment of solar PV systems using LCC and $\mathrm{LCCO}_{2}$ analyses (Hong et al. 2013; Kim et al. 2012; Lee et al. 2015a). Basically, assumptions on six items should be defined: (i) analysis approach; (ii) analysis period; (iii) analysis point; (iv) real discount rate; (v) inflation rate; and (vi) significant cost of ownership (Dell'Isola, Kirk 2003). Table 2 shows the assumptions for $\mathrm{LCC}$ and $\mathrm{LCCO}_{2}$ analyses.

\subsubsection{Step 3.1: Analysis period}

The previous studies on the economic analysis of solar PV systems set the useful life of the solar PV system at between 20 and 40 years (Branker et al. 2011; Swift 2013). If the actual service life of the solar PV system, however, exceeds the warranty period, the solar PV panel performance cannot be guaranteed due to the degradation of the solar PV system. Besides, due to the increased operation and maintenance costs, the solar PV panel reaches its economic life. Thus, the warranty period determined by the solar PV panel manufacturers (usually between 20 and 25 years) is generally used as the useful life of the solar PV system (Brearley 2009). Based on the actual useful life of the solar PV system of Yingli Solar, this study set 25 years as the analysis period (Yingli Solar 2015). 
Table 2. Assumptions for $\mathrm{LCC}$ and $\mathrm{LCCO}_{2}$ analyses

\begin{tabular}{|c|c|c|c|c|}
\hline \multicolumn{4}{|c|}{ Category } & Description \\
\hline \multicolumn{4}{|c|}{ Analysis approach } & Present worth method \\
\hline \multicolumn{4}{|c|}{ Analysis period } & 25 years \\
\hline \multicolumn{4}{|c|}{ Analysis point } & 2013 \\
\hline \multirow{4}{*}{$\begin{array}{l}\text { Real } \\
\text { discount } \\
\text { rate }\end{array}$} & \multicolumn{3}{|c|}{ Inflation rate } & $1.98 \%$ \\
\hline & \multicolumn{3}{|c|}{ Electricity price growth rate } & varies by state \\
\hline & \multicolumn{3}{|c|}{ SREC $^{\text {a }}$ price growth rate } & varies by state \\
\hline & \multicolumn{3}{|c|}{$\mathrm{CO}_{2}$ Emission trading price growth rate } & $-0.67 \%$ \\
\hline \multirow{11}{*}{$\begin{array}{l}\text { Significant } \\
\text { cost of } \\
\text { Ownership }\end{array}$} & \multicolumn{3}{|c|}{ Installation cost of the solar PV system } & $\$ 5,200 / \mathrm{kW}$ \\
\hline & \multirow[t]{2}{*}{ Cost } & \multirow{2}{*}{$\begin{array}{l}\text { Maintenance } \\
\text { and } \\
\text { replacement } \\
\text { cost }\end{array}$} & $\begin{array}{c}\text { Maintenance and insurance } \\
\text { Cost }\end{array}$ & $\begin{array}{l}1 \% \text { of the installation cost } \\
\text { (annually) }\end{array}$ \\
\hline & & & Inverter Replacement Cost & $\begin{array}{l}9.5 \% \text { of the installation cost } \\
\text { (in year 13) }\end{array}$ \\
\hline & \multirow{8}{*}{ Benefit } & \multirow{6}{*}{$\begin{array}{c}\text { Solar } \\
\text { incentives }\end{array}$} & Federal income tax credit & $30 \%$ of the installation cost \\
\hline & & & State income tax credit & varies by state \\
\hline & & & Property tax exemption & varies by state \\
\hline & & & Sales tax exemption & varies by state \\
\hline & & & Capacity-based incentives & varies by state \\
\hline & & & Performance-based incentives & varies by state \\
\hline & & \multirow{2}{*}{$\begin{array}{l}\text { Energy } \\
\text { benefit }\end{array}$} & Electricity price & varies by state \\
\hline & & & $\mathrm{CO}_{2}$ Emission trading price & $\$ 9.51 \mathrm{TCO}_{2 \mathrm{eq}}$ \\
\hline
\end{tabular}

Note: ${ }^{a}$ SREC refers to solar renewable energy certificates.

\subsubsection{Step 3.2: Real discount rate}

Using the nominal interest rate, inflation rate, electricity price growth rate, SREC price growth rate, and $\mathrm{CO}_{2}$ emission trading price growth rate, this study calculated the real discount rate. The real discount rate was derived from Eq (1):

$$
i=\frac{\left(1+i_{n}\right)}{(1+f)}-1,
$$

where: $i$ stands for the real discount rate; $f$ stands for one of the following: inflation rate, electricity price growth rate, SREC price growth rate, or $\mathrm{CO}_{2}$ emission trading price growth rate; and $i_{n}$ stands for the nominal interest rate.

First, in order to calculate the real discount rate, the nominal interest rate was calculated using the federal funds rate of U.S. Federal Reserve Board (FRB), and the inflation rate was calculated using the data provided by USInflation.org, an inflation rate and consumer price index portal in the U.S. (FRB 2015; USInflation.org 2015). Since the nominal interest rate and the inflation rate may vary from year to year, this study used the average value of the nominal interest rate and the inflation rate from 2002 to 2012 in order to make the analysis more reliable (refer to SI Table S3). As a result, the real discount rate was calculated as $1.98 \%$ (refer to Table 2). Second, in order to calculate the real discount rate 
for electricity, the electricity price growth rate was calculated using the annual residential average retail price of electricity from 2001 to 2012 provided by EIA (EIA 2015). As the electricity price differs by state, this study used electricity price data by state. As a result, the real discount rate for electricity in each state was calculated as shown in SI Table S4 (i.e., SI Tables S4A and S4B). Third, in order to calculate the real discount rate for SREC, the SREC price growth rate for those states with SREC market was calculated based on the SACP by state from 2013 to 2023, which is offered by SRECTrade, an SREC trade portal (SRECTrade 2015). As SACP is the penalty on non-compliance with SREC requirements, it reflects the SREC price change from year to year (Lee et al. 2015b). In the U.S., eight states, the District of Columbia, Delaware, Massachusetts, Maryland, North Carolina, New Jersey, Ohio, Pennsylvania, have their own SREC markets (DSRIE 2015, SRECTrade, 2015). Among these states, except for North Carolina, which has no SACP regulation, and Pennsylvania, which provide the SACP prices yearly, all other states provide their own SACP price schedules for the next 10 to 20 years. Therefore, this study calculated the SREC price growth rate only for these six states by using each state's SACP price schedules. As a result, the real discount rate for SREC in each state was calculated as shown in SI Table S5. Fourth, in order to calculate the real discount rate for $\mathrm{CO}_{2}$ emission, the $\mathrm{CO}_{2}$ emission trading price growth rate was calculated using the average value of the $\mathrm{CO}_{2}$ emission trading price forecasts in the U.S. from 2020 to 2031 provided by the Synapse Energy Economics report (Wilson et al. 2012). As a result, the real discount rate for $\mathrm{CO}_{2}$ emission was calculated as $-0.67 \%$ (refer to Table 2).

\subsubsection{Step 3.3: Significant cost of ownership}

This study considered the initial investment cost and operation and maintenance cost of solar PV systems for the cost item, and the solar incentives and energy benefit for the benefit item.

First, the cost item for the solar PV system was set as shown below:

- Installation cost of the solar PV system: Lawrence Berkeley National Laboratory regularly publishes Tracking the Sun, a report on the historical data on the installation cost of the solar PV system in the U.S. This study assumed US $\$ 5,200 / \mathrm{kW}$ as the installation cost of the solar PV system, based on the latest version of the publication, Tracking the Sun VI (Barbose et al. 2013); and,

- Maintenance and replacement cost: according to the previous studies, the annual maintenance and insurance cost is normally $1 \%$ of the installation cost of the solar PV system; and the inverter replacement cost, 9.5\% (Branker et al. 2011; Burns, Kang 2012; Swift 2013). In addition, the inverter should be replaced 13 years after its first installation (Swift 2013). Thus, this study set $1 \%$ and $9.5 \%$ of the installation cost of the solar PV system as the annual maintenance and insurance cost and the inverter replacement cost, respectively.

Second, the benefit item for the solar PV system was set as shown below:

- Solar incentives: the solar incentives can be divided into tax incentives (i.e., income tax credit and tax exemption) and cash incentives (i.e., capacity- and performancebased incentives), and the amount of the payment differs by state. In a state where 
there is no property tax exemption, however, a property tax is imposed on a home value which is increased due to the installation of the solar PV system. Therefore, in conducting the LCC analysis of the solar PV system in a state without property tax exemption, the increased home value due to the installation of the solar PV system should be considered. Nevin and Watson (1998) standardized and used as an index the increased home value due to the installation of the solar PV system, using Eq (2) (Nevin, Watson 1998); and,

$$
I H V=E C S_{a} \times 20,
$$

where: $I H V$ stands for the increased home value; and $E C S_{a}$ stands for the annual energy cost savings.

- Energy benefit: the energy benefit can be divided into the electricity price and the $\mathrm{CO}_{2}$ emission trading price. First, to assess the economic aspects of the energy benefit using LCC analysis, this study used the residential average retail price of electricity by state as the electricity price. Next, to assess the environmental aspects of the energy benefit using $\mathrm{LCCO}_{2}$ analysis, this study used the $\mathrm{CO}_{2}$ emission trading price data, which is required to convert the $\mathrm{CO}_{2}$ emissions reduced by the electricity generation of the solar PV system into an economic value. The $\mathrm{CO}_{2}$ emission trading price was set at US\$9.51/TCO $\mathrm{TCq}_{2 \mathrm{eq}}$ based on IEA's report, and the $\mathrm{CO}_{2}$ emission reduction was calculated using 3) (IEA 2013).

$$
C E\left(t \mathrm{CO}_{2}\right)=E G(k W h) \times C F-\left(\frac{t \mathrm{CO}_{2}}{M W h}\right) \times\left(\frac{1}{10}\right)^{3},
$$

where: $C E$ stands for the $\mathrm{CO}_{2}$ emission reduction; $E G$ stands for the electricity generation; and $C F$ stands for the $\mathrm{CO}_{2}$ emission factor for electricity $\left(0.4705 t \mathrm{CO}_{2} / M W h\right)$.

\subsection{Step 4: Economic assessment of the residential solar PV systems}

Based on the data collected and the assumptions defined in steps 1 3, this study conducted an economic assessment of residential solar PV systems considering the state solar incentives in the U.S. This study used net present value (NPV), profitability index (PI), and payback period (PP) to conduct a multilateral break-even analysis and impact analysis of the residential solar PV systems based on LCC and $\mathrm{LCCO}_{2}$ analyses (Farris et al. 2010; Hong et al. 2014b).

\subsubsection{Step 4.1: Net present value (NPV)}

NPV, the sum of the present value of the cash inflow and outflow which is discounted back based on the real discount rate, is used to determine the economic feasibility of a project. Generally, a project is economically feasible if "NPV $>0$ ", indicating that the break-even point has been reached. This study calculated the NPV using Eq (4):

$$
N P V=\sum_{t=0}^{n} \frac{B_{t}}{(1+r)^{t}}-\sum_{t=0}^{n} \frac{C_{t}}{(1+r)^{t}},
$$

where: $N P V$ stands for the net present value; $B_{t}$ stands for the benefit in year $t ; C_{t}$ stands for the cost in year $t ; r$ stands for the real discount rate; and $n$ stands for the analysis period. 
The benefit in year $t\left(B_{t}\right)$ and the cost in year $t\left(C_{t}\right)$ can be calculated using Eqs (5) and (6), respectively. Tax exemption, among the solar incentives, is calculated not as a profit but as an additional cost in a target city where no tax exemption exists. Therefore, tax exemption was considered in calculating the cost in year $t\left(C_{t}\right)$, not in calculating the benefit in year $t\left(B_{t}\right)$.

$$
B_{t}=I T C_{t}+C B I_{t}+P B I_{t}+\left(E G_{t} \times P o E_{t}\right)+\left(C E_{t} \times C P_{t}\right),
$$

where: $B_{t}$ stands for the benefit in year $t$; ITC $t$ stands for the benefit from the income tax credit in year $t ; C B I_{t}$ stands for the benefit from the capacity-based incentives in year $t$; $P B I_{t}$ stands for the benefit from the performance-based incentives in year $t ; E G_{t}$ stands for the electricity generation in year $t ; P_{o} E_{t}$ stands for the average retail price of electricity in year $t$; $C E_{t}$ stands for $\mathrm{CO}_{2}$ emissions reduction in year $t$; and $C P_{t}$ stands for $\mathrm{CO}_{2}$ emission trading price in year $t$.

$$
C_{t}=\left(I C_{P V} \times\left(1+r_{s}\right)\right)+O M C_{t}+\left(I H V_{t} \times r_{p}\right),
$$

where: $C_{t}$ stands for the cost in year $t ; C_{P V}$ stands for the installation cost of the solar PV system in year $t ; r_{s}$ stands for the sales tax rate; $O M C_{t}$ stands for the operation and maintenance cost in year $t$; $I H V_{t}$ stands for the increased home value in year $t$; and $r_{p}$ stands for the property tax rate.

\subsubsection{Step 4.2: Profitability index (PI)}

PI, the ratio between the present value of the cash inflow and outflow which is discounted back based on the real discount rate, is used to determine the economic feasibility of a project. Generally, a project is economically feasible if "PI $\geq 1$ ", indicating that the break-even point has been reached. While NPV is an absolute index in LCC analysis, PI is a relative index. This study calculated PI using Eq (7). The benefit in year $t\left(B_{t}\right)$ and the cost in year $t\left(C_{t}\right)$ can be calculated using Eqs (5) and (6), respectively:

$$
P I=\left(\sum_{t=0}^{n} \frac{B_{t}}{(1+r)^{t}}\right) /\left(\sum_{t=0}^{n} \frac{C_{t}}{(1+r)^{t}}\right),
$$

where: $P I$ stands for the profitability index; $B_{t}$ stands for the benefit in year $t ; C_{t}$ stands for the cost in year $t ; r$ stands for the real discount rate; and $n$ stands for the analysis period.

\subsubsection{Step 4.3: Payback period (PP)}

$\mathrm{PP}$, the length of time required to retrieve the cash outflow from the total investment benefit, is used to determine the economic feasibility of a project. PP signifies the length of time required for the NPV of the annual cumulative benefit to be equal to the NPV of the annual cumulative cost. That is, the break-even point, at which the investment cost and investment benefit for the installation of the solar PV system are equal, can be easily determined with PP. When determining the economic feasibility of a project using PP, it is effective to compare the calculated PP to the target PP. An index that is relatively easy to understand, PP can be conveniently used by the decision makers for the solar PV system installation. 


\section{Results and discussion}

This study conducted an economic assessment of the residential solar PV systems in the 50 states and the District of Columbia to analyze the regional diversity of the state solar incentives in the U.S.

\subsection{Economic assessment of the residential solar PV systems}

\subsubsection{Economic assessment based on the deterministic approach}

SI Table S6 (i.e., SI Tables S6A and S6B) and Figures 1 to 3 show the results of the LCC and $\mathrm{LCCO}_{2}$ analyses using the NPV, PI, and PP indices. SI Table S6 shows the results of both solar incentives' NPV and LCC and $\mathrm{LCCO}_{2}$ analysis. Based on the incentive payment methods, the solar incentives' NPV was categorized into up-front incentives (i.e., federal income tax credit, state income tax credit, state rebate program, and utility rebate program), annual incentives (i.e., state program, utility program, and SREC), and tax exemption (i.e., property and sales tax exemptions). The up-front incentives are paid once at the first installation of the solar PV system, and the annual incentives are paid annually based on the amount of annual electricity generation. As tax exemption is not a profit but an additional cost in a target city where no tax exemption exists, it was expressed with a negative value. Figures 1 to 3 show the economic assessment of the residential solar PV systems based on the state solar incentives. Figures 1 and 2 show the results of the NPV and PI, respectively. The greener the color of the state, the higher the state's NPV and PI, and the higher the economic performance of the solar PV system. Figure 3 is the result of the PP, where the greener the color of the state, the faster the PP occurs. Meanwhile, the grey color means that no PP occurred within 25 years, thus failing to reach the break-even point. It is expected that such maps will make the decision making process much easier in installing the solar PV system.

\subsubsection{Sensitivity analysis using Monte Carlo Simulation (MCS)}

Since there are uncertainties due to various assumptions made during LCC and $\mathrm{LCCO}_{2}$ analysis, it is important to conduct sensitivity analysis considering various assumptions (Hong et al. 2013). Especially, a slight difference in the real discount rate may change the LCC and $\mathrm{LCCO}_{2}$ analysis results drastically. Therefore, this study conducted sensitivity analysis considering real discount rate using Monte Carlo Simulation (MCS). Software called Crystal Ball was used for MCS. First, three types of uncertainties which causes changes in real discount rate were defined as assumptions for MCS as follows: (i) nominal interest rate; (ii) inflation rate; and (iii) electricity price growth rate. Second, these three assumptions were defined as normal distribution, which explains many natural phenomena such as people's heights, the inflation rate, or errors in measurements, using the mean and standard deviation of each data from 2002 to 2012. Third, NPV and PI of the residential solar PV system were defined as forecast value for MCS.

After conducting 5,000 simulations for each target cities, the probability distributions for the NPV and the PI were estimated. Accordingly, the NPV and PI for each target cities were calculated based on the median value of each probability distribution. 


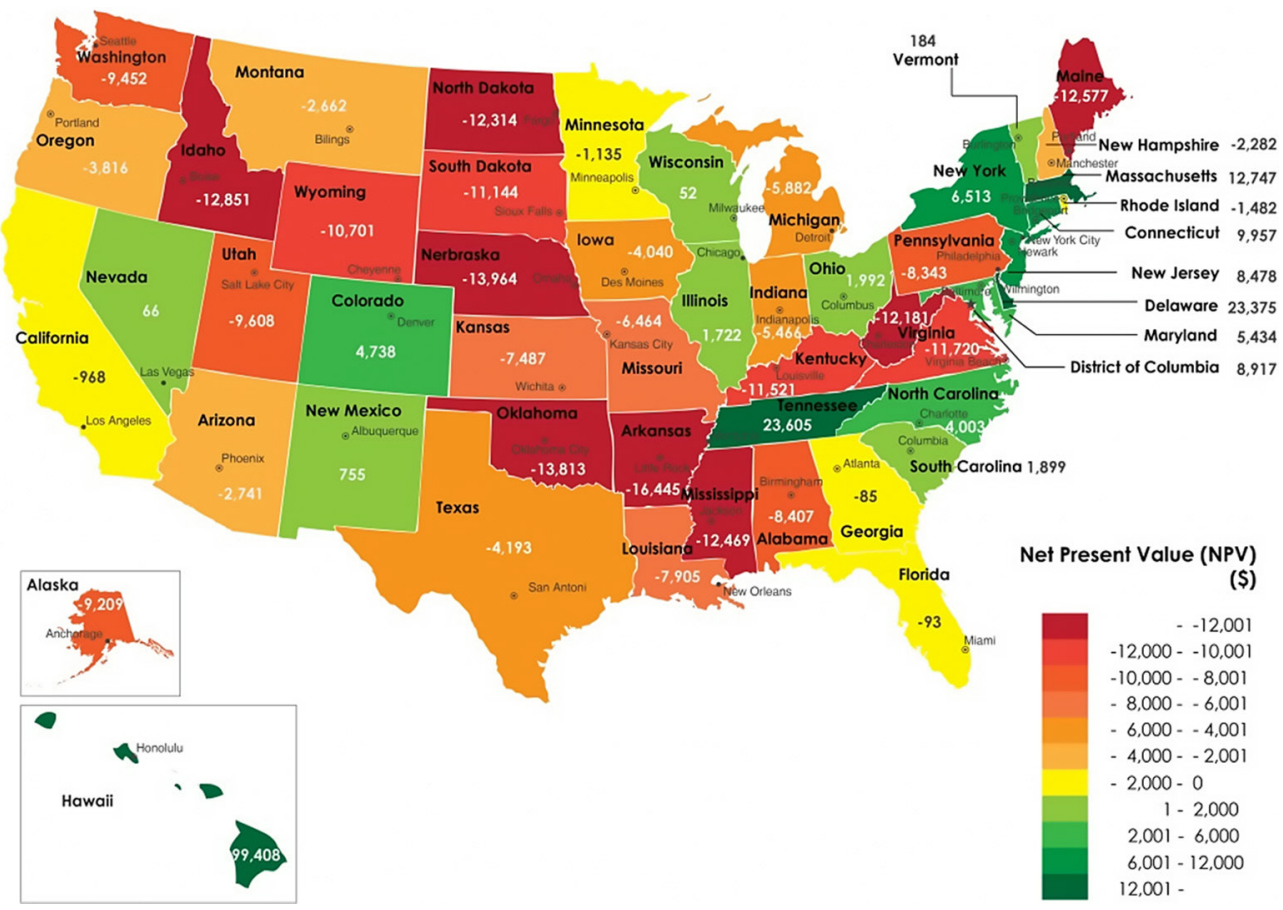

Fig. 1. Net present value map of residential solar PV system by target city in each state

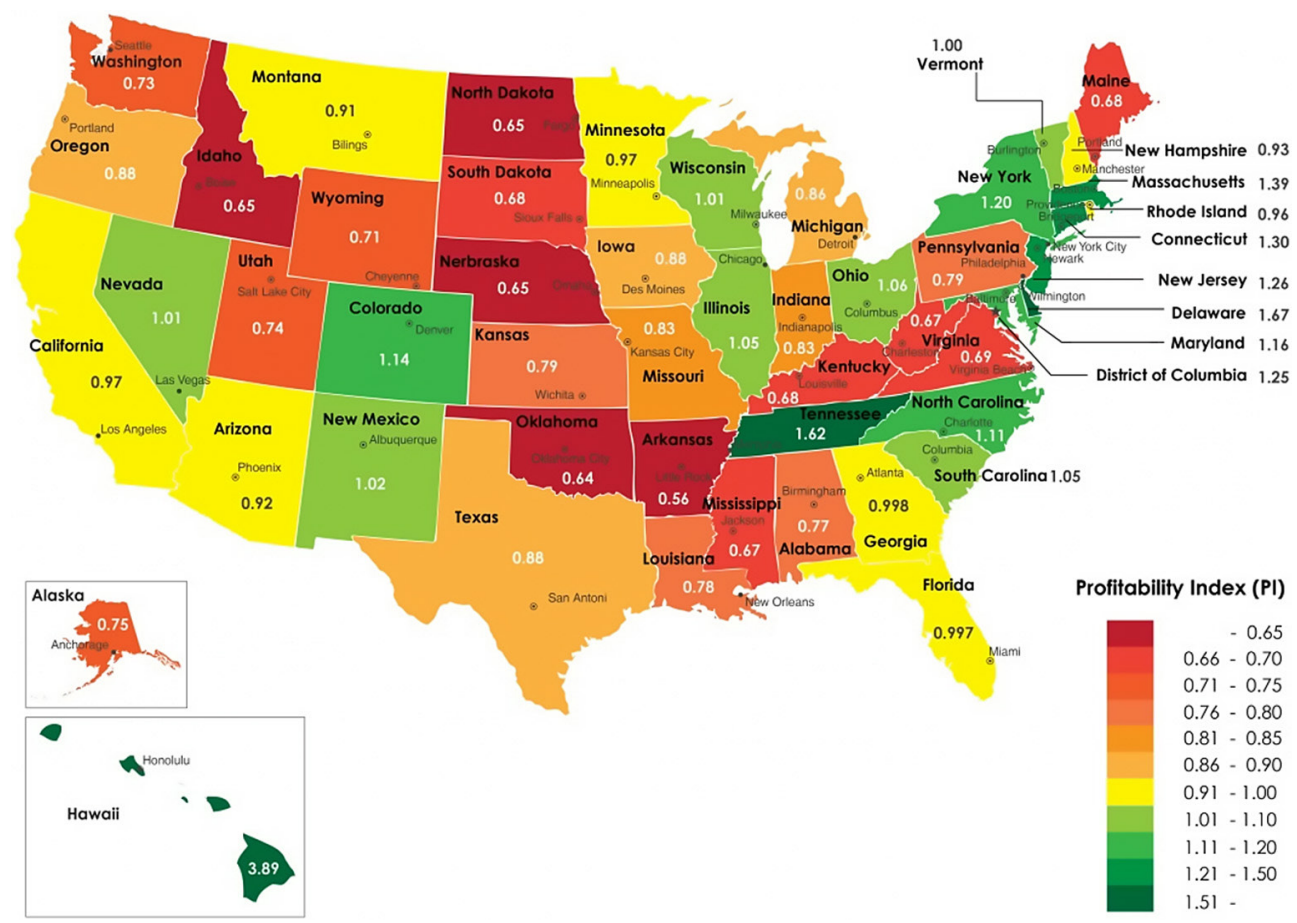

Fig. 2. Profitability index map of residential solar PV system by target city in each state 


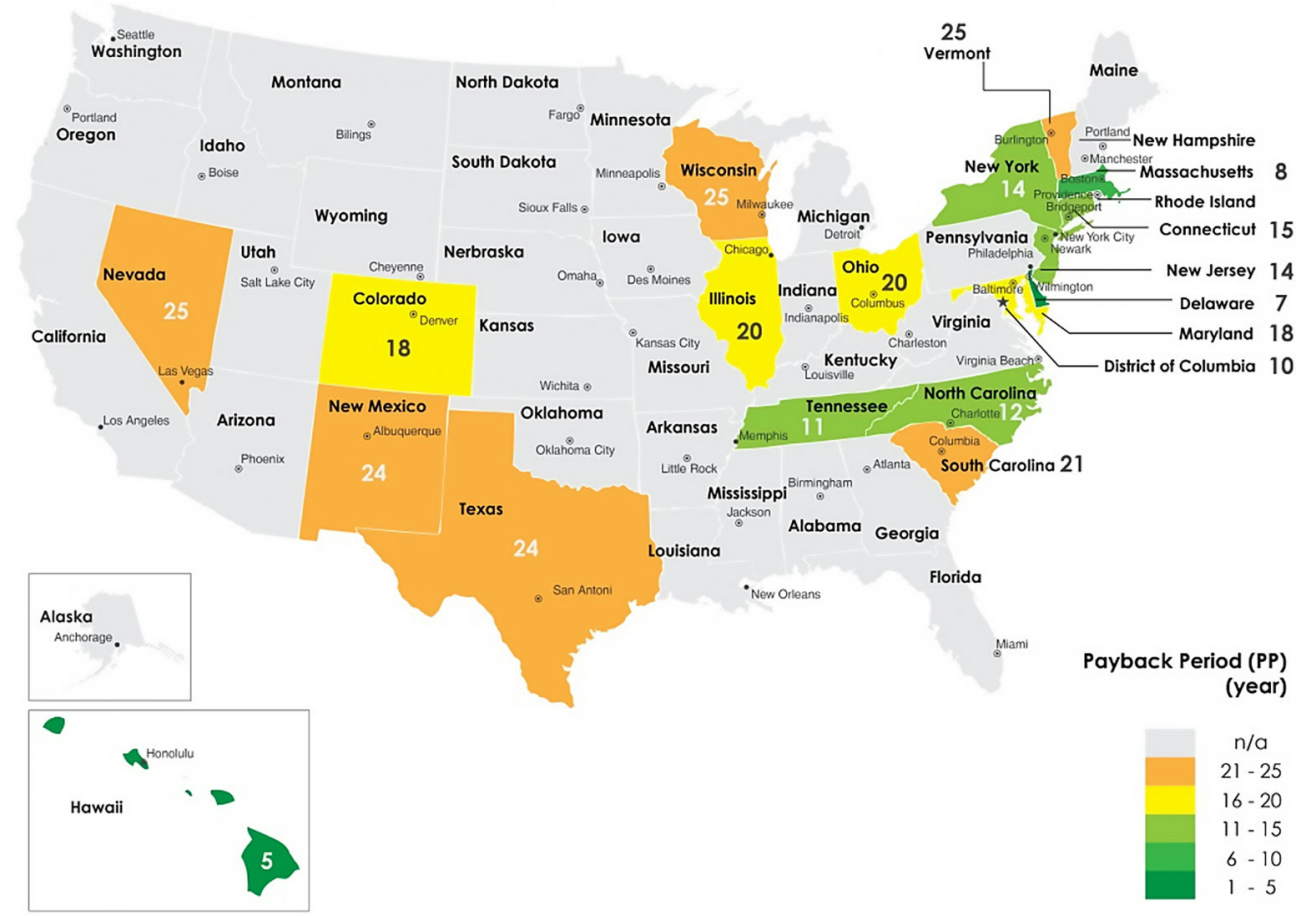

Fig. 3. Payback period map of residential solar PV system by target city in each state

By comparing the NPV and PI calculated based on the deterministic approach (i.e. NPV and $\mathrm{PI}_{\mathrm{d}}$, respectively) to the NPV and PI calculated based on the stochastic approach (i.e. $\mathrm{NPV}_{\mathrm{s}}$ and $\mathrm{PI}_{\mathrm{s}}$, respectively), it was shown that the $\mathrm{NPV}_{\mathrm{d}}$ was calculated with an accuracy of $87.19 \%$ 99.99\%, having mean absolute percentage error (MAPE) of $2.38 \%$ (refer to SI Table S7). Similarly, the $\mathrm{PI}_{\mathrm{d}}$ was calculated with an accuracy of $98.20 \% \sim 100.00 \%$, having MAPE of $0.31 \%$ (refer to SI Table S7). This indicates that the $\mathrm{NPV}_{\mathrm{d}}$ and $\mathrm{PI}_{\mathrm{d}}$ are highly reliable and reasonable. The detailed probability distribution results of Memphis in Tennessee as a sample can be found in SI Figures S6 and S7.

\subsection{Break-even point analysis}

\subsubsection{Positive cases}

As shown in SI Table S6 and Figures 1 to 3, when residential solar incentives were offered, 18 out of the 51 target cities could reach the break-even point. The NPV, PI, and PP in these 18 cities were US\$66 US\$99,408, 1.002 3.889, and 5 25 years, respectively. The reasons for the success to reach the break-even point were analysed as below.

First, the NPV and PP in Honolulu, Hawaii when the solar PV system was installed were US\$99,408 and five years, respectively. Honolulu showed the highest profit among the 51 target cities, and reached the break-even point the fastest. The NPV in Honolulu was four times higher than the NPV of the second- and third-ranking cities, respectively, Mem- 
phis in Tennessee (US\$23,605) and Wilmington in Delaware (US\$23,375). Compared to the other regions, Honolulu was shown to have considerably higher profits from the solar PV system. It is because the residential average retail price of electricity in Hawaii is considerably higher than the other states, and therefore installing the solar PV system brought a huge impact despite the fact that the benefit from the solar incentives was relatively small (Hawaii offers only state income tax credit and property tax exemption).

Second, in Bridgeport in Connecticut, Wilmington in Delaware, Boston in Massachusetts, Baltimore in Maryland, Newark in New Jersey, New York City in New York, Burlington in Vermont, and Milwaukee in Wisconsin, the break-even point for the solar PV system was reached due to the high residential average retail price of electricity and solar incentives. In Wilmington, particularly, the benefit of the solar incentives was shown to be US $\$ 32,505$ due to the high SREC price and capacity-based incentives. As a result, the NPV was US\$23,375, the PI was 1.674, and the PP was seven years, showing the high economic value of the solar PV system.

Third, in Denver in Colorado, Charlotte in North Carolina, Albuquerque in New Mexico, Las Vegas in Nevada, and Memphis in Tennessee, the break-even point of the solar PV system was reached due to the high electricity generation and solar incentives. In Memphis, particularly, capacity-based incentives and performance-based incentives were offered at the same time, and the benefit from the performance-based incentives is as much as US\$33,953, resulting in the second highest NPV, following Honolulu in Hawaii.

Fourth, in the District of Columbia, Chicago in Illinois, and Columbus in Ohio, the break-even point of the solar PV system was reached despite the unfavorable conditions of generating electricity from the solar PV system (i.e., a low residential average retail price of electricity or electricity generation). Namely, the solar incentive benefits in the District of Columbia, Chicago, and Columbus were US\$21,744, US\$19,203, and US\$18,382, respectively, showing that the break-even point was reached and that solar PV system investment is feasible due to the superior solar incentives. In the District of Columbia, in particular, while the types of solar incentives are not diverse, the solar weighted average price per SREC is US\$397, which is the most expensive among all the states. Thus, the economic performance of the solar PV system was shown to be excellent, with an NPV of US\$8,917, a PI of 1.256 , and a PP of 10 years.

\subsubsection{Negative cases}

In the 33 cities whose break-even point could not be reached, the NPV and PI were US\$-16,445 US\$-85 and 0.559 0.998, respectively. The reasons for the failure to reach the break-even point were analysed as below.

First, despite the advantageous conditions of generating electricity from the solar PV system (i.e., the high residential average retail price of electricity and high electricity generation) in Los Angeles in California, the break-even point of the solar PV system was not reached. The PI was 0.953 , and the break-even point was almost reached, but due to the low solar incentives, the break-even point failed to be reached.

Second, despite the advantageous conditions of generating electricity from the solar PV system (i.e., high electricity generation), Phoenix in Arizona, Wichita in Kansas, Oklahoma 
City in Oklahoma, San Antonio in Texas, Salt Lake City in Utah, and Cheyenne in Wyoming could not reach the break-even point. In Oklahoma City, particularly, the additional cost of US $\$ 4,470$ was paid due to the non-existence of tax exemption, resulting in an NPV and PI of US\$-13,813 and 0.636, respectively, and making it difficult to make the solar PV system economically feasible.

Third, despite the advantageous conditions of generating electricity from the solar PV system (i.e., the high residential average retail price of electricity), the break-even point of the solar PV system was not reached in Anchorage in Alaska, Portland in Maine, Detroit in Michigan, Manchester in New Hampshire, Philadelphia in Pennsylvania and Providence in Rhode Island. Particularly, in the six target cities except for Manchester and Providence, the expenses due to the non-existence of tax exemption were US\$4,233 US\$7,936, making it difficult to make the solar PV system economically feasible.

Fourth, the cities that could not reach the break-even point despite the high benefit from solar incentives were Atlanta in Georgia, New Orleans in Louisiana, Miami in Florida, and San Antonio in Texas, showing the low impact of solar incentives. With a PI of 0.998, Atlanta almost reached the break-even point, but the US\$4,855 expenses due to the nonexistence of tax exemption failed to bring about the effect of high up-front and annual incentives. Due to the low residential average retail price of electricity in New Orleans, high solar incentives could not help the state reach the break-even point.

\subsection{Impact analysis of solar state incentives}

Figure 4 shows the results of the analysis of the impact of the state solar incentives on the economic feasibility of the residential solar PV systems. Namely, Figure 4 compares and analyzes the PI values of scenario 1 (the case without state solar incentives) and scenario 2 (the case with state solar incentives). In Figure 4, the x-axis shows the PI when state solar incentives were not available (scenario 1), and the y-axis shows the PI when state solar incentives were available (scenario 2). According to the PI increase ratio of scenarios 1 and 2, which can be identified as slope between PI of scenarios 1 and 2, groups (A)-(F) (illustrated in green-orange color scale in Fig. 4) were classified. The closer it is to group (A) (i.e., the closer it is to green), the greater the PI increase ratio of scenarios 1 and 2. That is, the economic feasibility of solar PV systems due to the state solar incentives improves as the PI increase ratio of scenarios 1 and 2 increases. On the other hand, the size of the circle signifies the NPV difference between scenarios 1 and 2 when residential solar PV systems were installed in the target cities in each state. The larger the circle is, the higher the profit caused by the state solar incentives. In general, the larger the circle is, the greater the PI increase ratio of scenarios 1 and 2. Using the following Eq (8), the PI increase ratios were calculated. SI Table S7 shows the classification criteria for groups (A)-(F).

$$
P I_{r}=\frac{P I_{2}}{P I_{1}},
$$

where: $P I_{r}$ stands for the PI increase ratio; $P I_{1}$ stands for the PI of scenario 1 ; and $P I_{2}$ stands for the PI of scenario 2. 


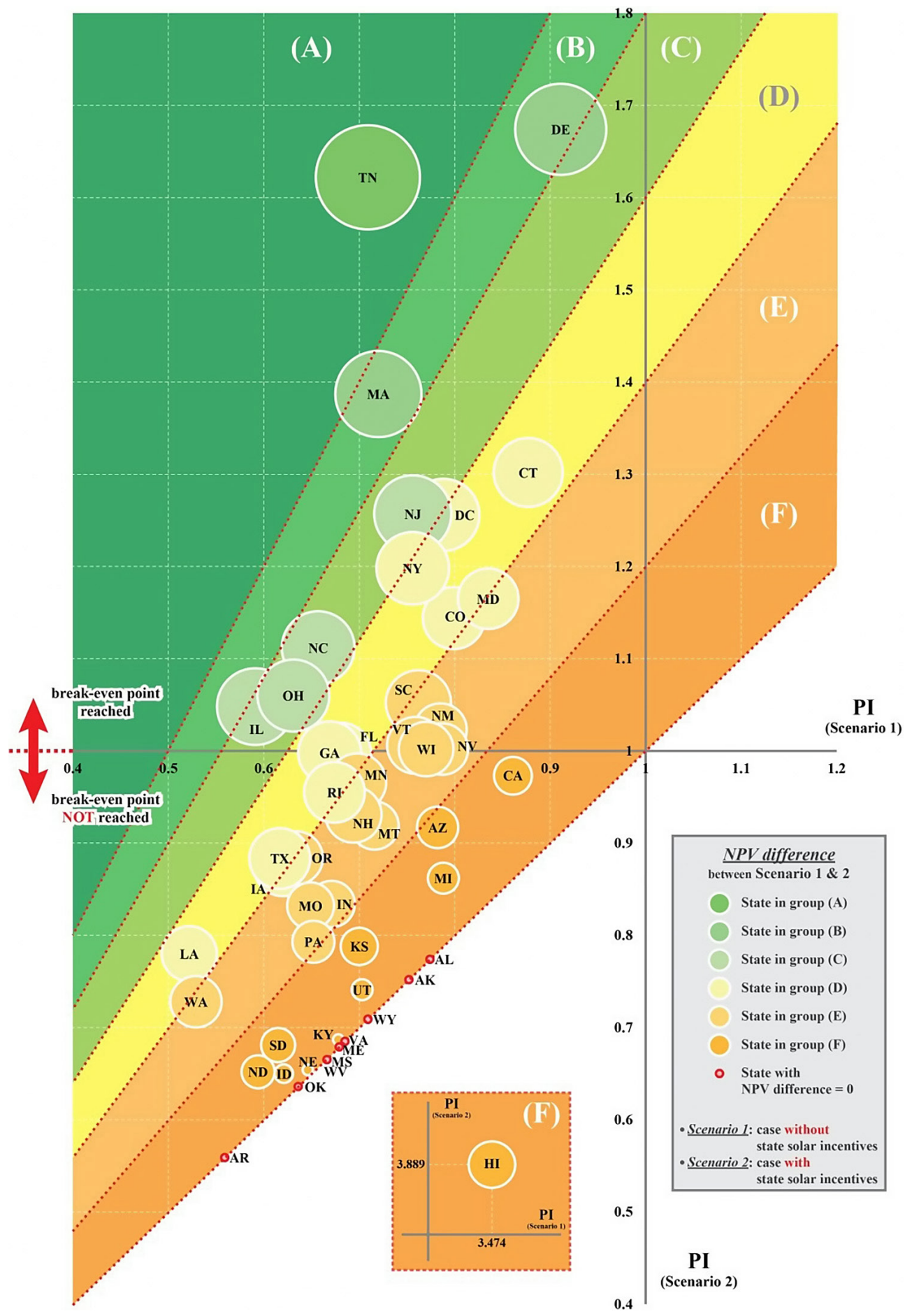

Fig. 4. Impact analysis of solar state incentives 
The detailed results of the analysis of the PI increase ratio of scenarios 1 and 2 were as below (refer to Fig. 4). First, Memphis in Tennessee was shown to have the highest PI increase ratio of scenarios 1 and 2 (group (A)). Due to the annual incentives, Memphis received US\$38,788, the highest incentive among all the cities, resulting in the greatest improvement of the economic feasibility of the solar PV systems by offering the state solar incentives.

Second, six cities, Wilmington in Delaware, Boston in Massachusetts, Newark in New Jersey, Charlotte in North Carolina, Columbus in Ohio, and Chicago in Illinois, had a 1.6 2 PI increase ratio (groups (B) and (C)). In Charlotte, Columbus, and Chicago, particularly, a very low economic feasibility was shown without state solar incentives (scenario 1), where the PI of the three cities in scenario 1 were $0.657,0.631$, and 0.591 , respectively. If state solar incentives were offered (scenario 2), the economic feasibility of the solar PV systems was considerably improved.

Third, among the 11 cities whose PI increase ratio was between 1.4 and 1.6 (group (D)), Bridgeport in Connecticut, the District of Columbia, New York City in New York, Baltimore in Maryland, and Denver in Colorado acquired economic feasibility by offering the state solar incentives, and could reach the break-even point. On the other hand, Miami in Florida, Atlanta in Georgia, Providence in Rhode Island, San Antonio in Texas, Des Moines in Iowa, and New Orleans in Louisiana could not reach the break-even point despite the fact that the economic feasibility of the solar PV systems slightly improved by offering the state solar incentives.

Fourth, the 23 other cities, including Los Angeles in California, Phoenix in Arizona, and Detroit in Michigan, where the PI increase ratio was below 1.4 (groups (E) and (F)), could not reach the break-even point despite that they showed little improvement on the economic feasibility of the solar PV systems by offering the state solar incentives. Exceptionally, Honolulu in Hawaii where the PI increase ratio was 1.12 (group (F)) was the only city that could reach break-even point in both scenario 1 and 2. Regardless of state solar incentives, Honolulu showed great economic feasibility of the solar PV system.

\section{Conclusions}

This study conducted an economic assessment of the residential solar PV systems in the 50 states and the District of Columbia by considering the existing state solar incentives in the U.S. Towards this end, the study conducted a break-even analysis using LCC and $\mathrm{LCCO}_{2}$ analyses and converted the economic and environmental values into NPV, PI, and PP. The analysis results were expressed in maps of NPV, PI, and PP to help in understanding the results easily and making decisions conveniently. Furthermore, to analyze the impact of the state solar incentives on the economic feasibility of the residential solar PV systems in each state, the study examined the PI increase ratio of scenario 1 (without state solar incentives) and scenario 2 (with state solar incentives). The main findings of this study can be summarized as below:

- When the residential solar incentives were offered, 18 of the 51 target cities could reach the break-even point. Particularly, several cities, including Bridgeport in Con- 
necticut, Wilmington in Delaware, Boston in Massachusetts, Baltimore in Maryland, Newark in New Jersey, New York City in New York, Burlington in Vermont, and Milwaukee in Wisconsin, could reach the break-even point due to the high residential average retail price of electricity and the excellent solar incentives.

- When the residential solar incentives were offered, 33 target cities could not reach the break-even point. Particularly, Anchorage in Alaska, Atlanta in Georgia, Portland in Maine, Detroit in Michigan, Oklahoma City in Oklahoma, and Philadelphia in Pennsylvania could not reach the break-even point because of the high expenses due to the non-existence of tax exemption in such cities.

- A total of seven cities, Memphis in Tennessee, Wilmington in Delaware, Boston in Massachusetts, Newark in New Jersey, Charlotte in North Carolina, Columbus in Ohio, and Chicago in Illinois, showed an excellent improvement on the economic feasibility of solar PV systems by offering the state solar incentives (PI increase ratio over 1.6). On the other hand, a total of 23 cities, including Los Angeles in California, Phoenix in Arizona, and Detroit in Michigan, showed a negligible improvement on the economic feasibility of solar PV systems by offering the state solar incentives (PI increase ratio below 1.4).

Based on the results of the break-even analysis and impact analysis in terms of state solar incentives, policy implications can be summarized as below:

- Although the up-front incentives were offered further in advance than the annual incentives, it was shown that the benefit from the annual incentives was larger from a long-term perspective. Particularly, Memphis in Tennessee offered US $\$ 33,953$ as annual incentives, over three times the up-front incentives. Therefore, states with limited budget can still encourage the residents to install the solar PV system by offering annual incentives, instead of up-front incentives which can be a financial burden on state governments.

- Having SREC markets in a state can benefit its residents with high annual incentives, which can encourage the introduction of the solar PV system. Most of the eastern states of the U.S. with a high residential average retail price of electricity reached the break-even point and showed superior economic performance of the solar PV system due to the high residential average retail price of electricity as well as the excellent solar incentives, SREC. Therefore, states, which have high residential average retail price of electricity or solar radiation but could not reach the break-even point, can encourage the residents to install the solar PV system by adopting SREC markets to their states.

- As statewide installed capacity of the solar PV system increases, most of the states reduce their state solar incentives. Particularly, despite the high solar radiation and residential average retail price of electricity, Los Angeles in California could not reach the break-even point due to insufficient capacity-based incentives which have fallen from US $\$ 2500 / \mathrm{kW}$ to US $\$ 200 / \mathrm{kW}$. Therefore, states should keep on boosting the installation of the residential solar PV system by allowing alternative political measures (e.g., SREC) which can reduce or offset the financial burden on residents. 
- The states, which generated high expenses due to the non-existence of tax exemption, could not reach the break-even point. Particularly, Detroit in Michigan, which generated the largest expenses due to the non-existence of tax exemption, generated an additional US $\$ 7,936$ as a tax, about $90 \%$ of the up-front incentives, making it difficult to encourage the installation of the solar PV system. Therefore, it is recommended for the state governments to offer at least tax exemption as a solar incentive in order to reduce the financial burden on their residents and encourage them to install the solar PV system.

It is expected that the results of this study (i.e., the results of the economic assessment of the residential solar PV systems by state) could help in the decision making process regarding the installation of the solar PV system. Also, these results can help policymakers to improve the existing solar incentive policies and to establish new ones by presenting the impact of the state solar incentives at a glance.

\section{Acknowledgement}

This work was supported by the National Research Foundation of Korea (NRF) grant funded by the Korea government (MSIP; Ministry of Science, ICT \& Future Planning) (No. NRF- 2015R1A2A1A05001657).

\section{References}

Ameli, N.; Kammen, D. M. 2014. Innovations in financing that drive cost parity for long-term electricity sustainability: an assessment of Italy, Europe's fastest growing solar photovoltaic market, Energy for Sustainable Development 19: 130-137. https://doi.org/10.1016/j.esd.2014.01.001

Antonelli, M.; Desideri, U. 2014. The doping effect of Italian feed-in tariffs on the PV market, Energy Policy 67: 583-594. https://doi.org/10.1016/j.enpol.2013.12.025

Barbose, G.; Darghouth, N.; Weaver, S.; Wiser, R. 2013. Tracking the Sun VI. California, Lawrence Berkeley National Laboratory (LBNL).

Branker, K.; Pathak, M. J. M.; Pearce, J. M. 2011. A review of solar photovoltaic levelized cost of electricity, Renewable and Sustainable Energy Reviews 15(9): 4470-4482. https://doi.org/10.1016/j.rser.2011.07.104

Brearley, D. 2009. C-Si photovoltaic trends: design, purchasing and 2009 specs, Solar Pro Magazine June/July: 49-74.

Burns, J. E.; Kang, J.-S. 2012. Comparative economic analysis of supporting policies for residential solar PV in the United States: Solar Renewable Energy Credit (SREC) potential, Energy Policy 44: 217-225. https://doi.org/10.1016/j.enpol.2012.01.045.

California Energy Commision (CEC) Energy Technology Development Division. 2001. A guide to photovoltaic $(P V)$ system design and installation. California, Endecon Engineering.

Darling, S. B.; You, F.; Veselka, T.; Velosa, A. 2011. Assumptions and the levelized cost of energy for photovoltaics, Energy and Environmental Science 4: 3133-3139. https://doi.org/10.1039/c0ee00698j.

Database of State Incentives for Renewables \& Efficiency (DSIRE). 2015. [online], [cited 20 April 2015]. Available from Internet: www.dsireusa.org 
Dell'Isola, A. J.; Kirk, S. J. 2003. Life cycle costing for facilities. Massachusetts, Reed Construction Data.

Farris, P. W.; Bendle, N. T.; Pfeifer, P. E.; Reibstein, D. J. 2010. Marketing metrics. New Jersey, Pearson Education.

Federal Reserve Bank (FRB). 2015. [online], [cited 20 April 2015]. Available from Internet: www.federalreserve.gov/releases/h15/data.htm\#fn11

Frondel, M.; Ritter, N.; Schmidt, C. M.; Vance, C. 2010. Economic impacts from the promotion of renewable energy technologies: the German experience, Energy Policy 38: 4048-4056. https://doi.org/10.1016/j.enpol.2010.03.029

Generation Attribute Tracking System (GATS). 2015. [online], [cited 20 April 2015]. Available from Internet: http://gats.pjm-eis.com/gats2/PublicReports/SolarWeightedAveragePrice

Hass, R.; Panzer, C.; Resch, G.; Ragwitz, M.; Reece, G.; Held, A. 2011. A historical review of promotion strategies for electricity from renewable energy sources in EU countries, Renewable and Sustainable Energy Reviews 15: 1003-1034. https://doi.org/10.1016/j.rser.2010.11.015

HIS Technology. 2014. PV Inverter World Market Report 2014. Colorado, HIS Technology.

Hong, S.; Jung, D. 2012. New and renewable energy law and policy. Seoul, Bobmunsa.

Hong, T.; Koo, C.; Kwak, T. 2013. Framework for the implementation of a new renewable energy system in an educational facility, Applied Energy 103: 539-551.

https://doi.org/10.1016/j.apenergy.2012.10.013

Hong, T.; Koo, C.; Park, J.; Park, H. 2014a. A GIS (geographic information system)-based optimization model for estimating the electricity generation of the rooftop PV (photovoltaic) system, Energy 65: 190-199. https://doi.org/10.1016/j.energy.2013.11.082

Hong, T.; Koo, C.; Kwak, T.; Park, H. 2014b. An economic and environmental assessment for selecting the optimum new renewable energy system for educational facility, Renewable and Sustainable Energy Reviews 29: 286-300. https://doi.org/10.1016/j.rser.2013.08.06.

International Energy Agency (IEA). 2011. Solar energy perspectives. Paris, IEA.

International Energy Agency (IEA). 2013. Tracking clean energy progress 2013. Paris, IEA.

Interstate Renewable Energy Council (IREC). 2013. U.S. Solar market trends 2012. New York, IREC.

Jiang, A.; Zhu, Y. 2012. Impact of incentives and system efficiency on the life cycle cost of photovoltaic systems, International Journal of Construction Education and Research 8(3): 204-222. https://doi.org/10.1080/15578771.2011.615892.

Kim, J.; Hong, T.; Koo, C. 2012. Economic and environmental evaluation model for selecting the optimum design of green roof systems in elementary schools, Environmental Science and Technology 46: 8475-8483. https://doi.org/10.1021/es2043855

Koo, C.; Hong, T.; Lee, M.; Park, H. 2013. Estimation of the monthly average daily solar radiation using geographical information system and advanced case-based reasoning, Environmental Science and Technology 47: 4829-4839. https://doi.org/10.1021/es303774a

Koo, C.; Hong, T.; Park, H.; Yun, G. 2014a. Framework for the analysis of the potential of the rooftop photovoltaic system to achieve the net-zero energy solar buildings, Progress in Photovoltaics: Research and Applications 22(4): 462-478. https://doi.org/10.1002/pip.2448

Koo, C.; Hong, T.; Kim, J.; Lee, M. 2014b. An integrated multi-objective optimization model for determining the optimal solution in the rooftop photovoltaic system, Renewable and Sustainable Energy Reviews 57: 822-837. https://doi.org/10.1016/j.rser.2015.12.205

Koo, C.; Hong, T.; Park, J. 2014c. Development of the life-cycle economic and environmental assessment model for establishing the optimal implementation strategy of the rooftop photovoltaic system, Technological and Economic Development of Economy (in press).

https://doi.org/10.3846/20294913.2015.1074127 
Korea Power Exchange (KPX). 2009. Global Electric Power Industry Trends. Seoul, KPX.

Laleman, R.; Albrecht, J. 2014. Comparing push and pull measures for PV and wind in Europe, Renewable Energy 61: 33-37. https://doi.org/10.1016/j.renene.2012.04.025

Lee, M.; Koo, C.; Hong, T.; Park, H. 2014. Framework for the mapping of the monthly average daily solar radiation using an advanced case-based reasoning and a Geostatistical technique, Environmental Science and Technology 48: 4604-4612. https://doi.org/10.1021/es405293u

Lee, M.; Hong, T.; Koo, C. 2015a. An economic impact analysis of state solar incentives for improving financial performance of residential solar photovoltaic systems in the United States, Renewable and Sustainable Energy Reviews 58: 590-607. https://doi.org/10.1016/j.rser.2015.12.297

Lee, M.; Hong, T.; Yoo, H.; Koo, C.; Kim, J.; Jeong, K.; Jeong, J.; Ji, C. 2015b. Establishment of a base price for the Solar Renewable Energy Credit (SREC) from the perspective of residents and state governments in the United States, Renewable and Sustainable Energy Reviews (in press).

https://doi.org/10.1016/j.rser.2016.11.086

Minister of Natural Resources. 2004. RETScreen international: results and impacts 1996-2012. Canada, Minister of Natural Resources.

Minister of Natural Resources. 2010. Clean energy project analysis: RETScreen engineering and cases textbook. Canada, Minister of Natural Resources.

Nevin, R.; Watson, G. 1998. Evidence of rational market valuations for home energy efficiency, The Appraisal Journal 68: 401-409.

Open PV Project Breakeven Analysis. 2015. [online], [cited 20 April 2015]. Available from Internet: http://openpv.nrel.gov/breakeven

PJM. 2015. [online], [cited 20 April 2015]. Available from Internet: http://www.pjm.com/about-pjm

Renewable Energy Policy Network for the 21 ${ }^{\text {st }}$ Century (REN21). 2013. Global Status Report 2013. Paris, REN21.

SolarPowerRocks. 2015. [online], [cited 20 April 2015]. Available from Internet: www.solarpowerrocks. com

SRECTrade. 2015. [online], [cited 20 April 2015]. Available from Internet: www.srectrade.com

Swift, K. D. 2013. A comparison of the cost and financial returns for solar photovoltaic systems installed by businesses in different locations across the United States, Renewable Energy 57: 137-143. https://doi.org/10.1016/j.renene.2013.01.011.

U.S. Energy Information Administration (EIA). 2015. [online], [cited 20 April 2015]. Available from Internet: www.eia.doe.gov

USInflation.org. 2015. [online], [cited 20 April 2015]. Available from Internet: http://usinflation.org/ us-inflation-rate/

Wilson, R.; Luckow, P.; Biewald, B.; Ackerman, F.; Hausman, E. 2012. 2012 Carbon dioxide price forecast. Massachusetts, Synapse Energy Economics.

Yingli Solar. 2015. [online], [cited 20 April 2015]. Available from Internet: www.yinglisolar.com/en/ 
Minhyun LEE. She is a PhD student in the Department of Architectural Engineering at Yonsei University. Her primary research areas include sustainable construction management system, building energy efficiency, new renewable energy, solar photovoltaics, carbon emissions reduction, geographic information system, decision support system, data-mining technique, case-based reasoning, life cycle cost analysis, building energy policy, and renewable energy policy.

Taehoon HONG. He is an Associate Professor in the Department of Architectural Engineering at Yonsei University. He is an associate editor in the Journal of Management in Engineering, ASCE. His main research areas include sustainable construction management system, building energy efficiency, solar photovoltaics, life cycle cost analysis, life cycle assessment, construction productivity, infrastructure management, facility management, and construction project cost control.

Choongwan KOO. He is an Assistant Professor in the Department of Building Services Engineering at The Hong Kong Polytechnic University and also a Research Professor in the Department of Architectural Engineering at Yonsei University. His primary research areas include sustainable construction management system, building energy efficiency, new renewable energy, solar photovoltaics, carbon emissions reduction, geographic information system, decision support system, data-mining technique, case-based reasoning, life cycle cost, life cycle assessment, multi-objective optimization for time-cost trade-off, and cost optimization.

Chan-Joong KIM. He is the vice president of NOWArchitects CO, Ltd in Seoul, Republic of Korea and also a PhD candidate in the Department of Architectural Engineering at Yonsei University. He is interested in the following research areas: sustainable construction management, construction industry business management, and construction project cost control. 